\title{
Evaluation of Mini Sling Complications and the Results of One Year-Treatment
}

\author{
Mini Sling Komplikasyonları ve \\ Bir Yıllık Tedavi Sonuçlarının Değerlendirilmesi
}

\author{
Mehmet Şükrü BUDAK, ${ }^{a}$ \\ Mehmet Baki ŞENTÜRK, ${ }^{b}$ \\ Sedat AKGÖL, ${ }^{\circ}$ \\ Mehmet Nafi SAKAR, ${ }^{a}$ \\ Varol NALCACIOĞLU, ${ }^{d}$ \\ Kenan ISEN ${ }^{d}$
}

Clinics of

aObstetrics and Gynecology, bUrology,

Gazi Yaşargil Training and Research Hospital, Diyarbakır, 'Clinic of Obstetrics and Gynecology, Bakırköy Dr. Sadi Konuk Training and Research Hospital, İstanbul, ${ }^{d} \mathrm{Clinic}$ of Obstetrics and Gynecology, Veni Vidi Hospital, Diyarbakır

Geliş Tarihi/Received: 09.12 .2014 Kabul Tarihi/Accepted: 05.03 .2015

Yazışma Adresi/Correspondence: Mehmet Şükrü BUDAK Gazi Yaşargil Training and Research Hospital,

Clinics of Obstetrics and Gynecology, Diyarbakır,

TÜRKIYE/TURKEY

dr_budak@mynet.com

doi: 10.5336/gynobstet.2014-42861

Copyright $@ 2015$ by Türkiye Klinikleri

\begin{abstract}
Objective: The aim of the study is to evaluate the complications and the results of one year treatment in patients subjected to mini sling operations due to stress urinary incontinence. Material and Methods: In this retrospective study, 48 patients subjected to mini sling operation due to stress urinary incontinence at Private Cizre Surgical Medical Center and Private Cizre Botan Hospital between $17^{\text {th }}$ of August 2012 and $12^{\text {th }}$ of October 2013. Results: In our study, the average age of the cases was $43.48 \pm 7.28$ years, the parity was $7.04 \pm 2.24$, and the average operation time was $7.21 \pm 1.34$ minutes. The negative cough stress test rate after mini sling was $91.7 \%$ at the $6^{\text {th }}$ week, $89.6 \%$ at $1^{\text {st }}$ year. In 1 of the cases $(2.1 \%)$ vaginal sulcus perforation as intraoperative complication, in 3 of the cases (6.3\%), postoperative inguinal pain and in 3 of the cases $(6.3 \%)$ de novo urge incontinence has been observed. No mesh erosion has been observed in any of the cases. Conclusion: Mini sling operations are minimally invasive; the short term results are comparable with traditional sling operations and the rate of complications is lower. Further studies are required for the determination of long-term success rates.
\end{abstract}

Key Words: Urinary incontinence, stress; treatment outcome; suburethral slings

ÖZET Amaç: Stres üriner inkontinans nedeniyle mini sling operasyonu yapılan hastaların komplikasyonları ve bir yıllık tedavi sonuçlarının değerlendirilmesidir. Gereç ve Yöntemler: Bu çalışmada 17 Ağustos 2012-12 Ekim 2013 tarihleri arasında Özel Cizre Cerrahi Tıp Merkezi ve Özel Cizre Botan Hospital'de stres üriner inkontinans nedeniyle mini-sling operasyonu yapılan 48 hasta retrospektif olarak değerlendirilmiştir. Bulgular: Çalışmamızda değerlendirilen olguların yaş ortalamaları 43,48 $\pm 7,28$ yıl, pariteleri $7,04 \pm 2,24$, ortalama operasyon süresi 7,21 $\pm 1,34$ dakikadır. Olguların mini sling sonrası negatif öksürük stres testi oranı 6 . haftada $\% 91,7,1$. yılda $\% 89,6$ 'dır. Olguların 1 $(\% 2,1)$ 'inde intraoperatif komplikasyon olarak vajinal sulkus perforasyonu, 3 (\%6,3)'ünde postop kasık ağrısı ve $3(\% 6,3)$ 'ünde de novo urge inkontinans görülmüştür. Olguların hiçbirinde mesh erozyonu ortaya çıkmamıştır. Sonuç: Mini sling operasyonları minimal invaziv, kısa dönem sonuçları geleneksel sling operasyonlarn ile kıyaslanabilir düzeyde iken komplikasyon oranları da daha düşüktür. Uzun dönem başarı oranlarının belirlenmesi için daha ileri çalışmalara gerek vardır.

Anahtar Kelimeler: Üriner inkontinans, stres; tedavi sonucu; subüretral slingler

Turkiye Klinikleri J Gynecol Obst 2015;25(2):99-102

tress urinary incontinence is supposed to affect $4-35 \%$ of adult women and to have negative effects on the quality of life of these affected women. ${ }^{1}$ In the last century, more than 100 surgical treatment methods have been proposed and the success rates of these techniques vary between 73 and $96 \% .^{2}$ Proposed for the first time in 1996, the utilization of tension-free vaginal tape (TVT) in stress urinary incontinence (SUI) treat- 
ment has been a breakthrough in this area. ${ }^{3}$ In 2001, the transobturator tape (TOT) has been developed by Delorme et al. ${ }^{4}$ In the following years, focus has been made on less invasive and more efficient techniques. In 2006, mini sling operations have started with the utilization of TVT-Secur and the short term success rates of this first mini sling procedure have been observed to be $10 \%$ lower than traditional sling operations. ${ }^{5,6}$ MiniArc ${ }^{\circledR}$ mini sling material developed later has presented short term success rates similar to traditional slings. ${ }^{7,8}$ Due to the prevention of blind dissection of retro pubic and inguinal, mini slings provide equal efficiency to standard miduretral slings together with decreased peri-operative morbidity incidence. ${ }^{9,10}$

The aim of this study is to evaluate the complications and the results of one year treatment in patients subjected to mini sling operations due to stress urinary incontinence.

\section{MATERIAL AND METHODS}

In this retrospective study, 48 patients subjected to mini sling operation due to stress urinary incontinence at Private Cizre Surgical Medical Center and Private Cizre Botan Hospital between $17^{\text {th }}$ of $\mathrm{Au}$ gust 2012 and $12^{\text {th }}$ of October 2013. All the patients have been subjected to gynecological examination in lithotomic position before operation. After checking that the bladder was filled at $>200 \mathrm{~mL}$ by ultrasound, cough stress test has been performed. After informing the patients with positive cough stress test (CST) about the operation, their approval has been obtained. All the operations have been performed by the same surgeon under spinal anesthesia conditions in operations room. After emptying the bladder of the patients using foley probe in lithotomic position, a $1.5 \mathrm{~cm}$ vertical cut $1.5 \mathrm{~cm}$ under external urethral meatus has been performed. The vaginal epithelium has been dissecated from the sub urethral area using scalpel, from the ascendant branch of the ischiopubic bone laterally to the obturator protecting the endopelvic fault. To reduce at the minimum the tissue damage, excessive traction has been prevented, and the utilization of cautery has been limited, aggressive posterior wall defect repair has been avoided in pa- tients with vaginal posterior wall defect to reduce the damage that may develop associated to physical pressure during advanced coitus and dissection has not been performed. Mesh extremities have been installed using trocar at each side of obturator internus muscle. After establishing a 1-2 mm space between mesh and urethra, an incision of $0.5 \mathrm{~cm}$ maximum using tissue scissors of the damaged vaginal mucosa by holding with clamps has been performed and the incision has been sutured after restoration. A povidon iodine roller tampon has been placed in the vagina and a $18 \mathrm{~F}$ foley probe has been installed in the bladder. Foley probe and vaginal tampon have been removed at the first post-operative day. The patients have been evaluated at the $6^{\text {th }}$ week and at the $12^{\text {th }}$ month following the operation. The patients with genital organ prolapse, other medical conditions and other incontinence types (Urge, Mixed, Overflow and functional incontinence) were excluded.

\section{STATISTICAL ANALYSIS}

When evaluating the results obtained in the study, IBM SPSS Statistics 22 (IBM SPSS, Turkey) software has been used for statistical analysis. When evaluating the data, defining statistics (average, standard deviation, frequency) have been used.

\section{RESULTS}

The study has been performed on 48 patients between $17^{\text {th }}$ of August 2012 and 12 $2^{\text {th }}$ of October 2013. The ages of the cases vary between 30 and 57 year old and the average is $43.48 \pm 7.28$ years. The parity number of the cases varies between 3 and 12, the average is $7.04 \pm 2.24$, the median is 7 . The operation times vary between 6 and $10 \mathrm{~min}$ and the average is $7.21 \pm 1.34$ minutes. Distribution of study parameters of the women undergoing mini sling operations due to SUI were summarized (Table 1).

The preoperation CST result of all the 48 cases (100\%) is positive. The CST at the postoperative 6 th week was positive for 4 of the cases (8.3\%), while the result was negative for 44 of them (91.7\%). The CST at the postoperative 1st year was positive for 5 of the cases (10.4\%), while the result was negative for 43 of them (89.6\%). 
Vaginal sulcus perforation has been observed as intraoperative complication in $1(2.1 \%)$ of the cases, postoperative inguinal pain in 3 of the cases $(6.3 \%)$ and de novo urge incontinence has been observed in 3 of the cases (6.3\%). No mesh erosion has been observed in any of the cases.

\section{DISCUSSION}

Nowadays, less invasive and reliable methods are preferred in SUI treatment in women. Complications are not reduced to zero in methods used individually and the success is not hundred \%. ${ }^{11}$

In our study, the average age of the cases was $43.48 \pm 7.28$ years, the parity was $7.04 \pm 2.24$, the average operation time was $7.21 \pm 1.34$ minutes. In the study of De Rider et al., the mean operation time was $11 \pm 6 \mathrm{~min}$, in the study of Moore et al. it was $7 \pm 3.4$ min and the results of both studies were similar to ours. ${ }^{7,12}$

In the study of De Rider et al., the negative CST result was $91 \%$ at the 6 th week and $85 \%$ at the $1^{\text {st }}$ year; in the study of Moore et al., the negative CST result $93 \%$ at the $12^{\text {th }}$ week and $91.4 \%$ at the $1^{\text {st }}$ year; in the study of Calvo et al. the negative CST result was $90 \%$ at the $101^{\text {st }}$ day. ${ }^{5,7,12}$ In our study, the negative CST result was $91.7 \%$ at the $6^{\text {th }}$ week and $89.6 \%$ at the $1^{\text {st }}$ year; the results of the three studies were similar.

Walsh et al. have analyzed 10 studies about mini sling and have indicated a $2.4 \%$ mesh erosion in 1178 cases. ${ }^{13}$ In a study performed by Taner et al. on 151 cases, this rate has been proposed as

\begin{tabular}{|lcc|}
\hline \multicolumn{2}{|c|}{ TABLE 1: Distribution of study parameters. } \\
\hline Parameters & n $\%$ \\
$\begin{array}{l}\text { Preoperation cough stress test } \\
\text { Cough stress test at the }\end{array}$ & Positive & 48100 \\
$\begin{array}{l}6^{\text {th }} \text { postop. week } \\
\text { Cough stress test at the }\end{array}$ & Negative & 4491,7 \\
$\begin{array}{l}1^{\text {st }} \text { postop. year } \\
\text { Vaginal sulcus perforation }\end{array}$ & 4389,6 \\
$\begin{array}{l}\text { Postoperation inguinal pain } \\
\text { Mesh erosion }\end{array}$ & Yes & 36,3 \\
De novo urge incontinence & No & 48100 \\
\hline
\end{tabular}

$4.6 \%{ }^{8}$ In a study on 61 cases of Moore et al., no mesh erosion has been reported. ${ }^{7}$ Similarly, in a series of De Rider et al. on 75 cases, no mesh erosion has been proposed. ${ }^{12}$ In our study as well, no mesh erosion has developed in any cases.

De Rider et al. have reported postoperative inguinal pain in $4 \%$ of the 75 patients series subjected to mini sling. ${ }^{12}$ Moore et al. did not report any postoperative inguinal pain in the 61 patient series. ${ }^{7}$ In our study, the postoperative inguinal pain rate was $6.6 \%$ and this result was similar to the result obtained by De Rider et al.

No intraoperative bladder and urethra wounding has been observed in our study. These two complications have not been reported in the literature. ${ }^{7,12}$ Moore et al. have reported intraoperative vaginal sulcus perforation in $1(1,3 \%)$ while Taner et al. have reported it in 6 cases $(3,9 \%)$ and the patients who developed vaginal sulcus perforation have been primarily sutured during the operation in these two studies. ${ }^{7,8}$ In the series of De Rider et al., no case of vaginal sulcus perforation has developed. ${ }^{12}$ In our study, it has developed in 1 case (2.1\%) and has been repaired by intraoperative primary suture.

In mini sling operations, iatrogenic artery injuries have been evaluated in 10 studies analyzed by Walsh et al.; internal pudental artery injury has developed in only one case and the necessity of radiological embolization to provide homeostasis has been reported. ${ }^{13}$ In our study, no iatrogenic artery injury has developed.

Taner et al. have reported de novo urge incontinence in patients subjected to mini sling in 10 cases (6.6\%). ${ }^{8}$ De Rider et al. have reported this situation in 5 cases (9\%). ${ }^{12}$ In our study, de novo urge incontinence has been determined in 3 cases (6.3\%). Our results are similar to those of Taner et al.

In conclusion, mini sling operations are minimal invasive operations used in SUI treatment and the short term results are comparable to traditional sling operations. Shorter operation times and less developed complications in patients subjected to mini sling are considered as advantages but further studies are required on this subject because long term success rates are not defined yet. 


\section{REFERENCES}

1. Luber KM. The definition, prevalence and risk factors for stress urinary incontinence. Rev Urol 2004;6(Suppl 3):S3-9.

2. Franco AVM, Fynes MM. Surgical treatment of stres incontinence. Current Obstet Gynecol 2004;14(6):405-11.

3. Ulmsten U, Henriksson L, Johnson P, Varhos G. An ambulatory surgical procedure under local anesthesia for treatment of female urinary incontinence. Int Urogynecol J Pelvic Floor Dysfunct 1996;7(2):81-5.

4. Delorme E, Droupy S, de Tayrac R, Delmas V. [Transobturator tape (Uratape). A new minimally invasive method in the treatment of urinary incontinence in women]. Prog Urol 2003; 13(4):656-9

5. Jiménez Calvo J, Hualde Alfaro A, Raigoso Ortega O, Cebrian Lostal JL, Alvarez Bandres $\mathrm{S}$, Jiménez Parra J, et al. [Our experience with mini tapes (TVT Secur and Miniarc) in the surgery for stres urinary incontinence]. Actas Urol Esp 2008;32(10):1013-8.
6. Meschia M, Barbacini P, Ambrogi V, Pifarotti $P$, Ricci L, Spreafico L. TVT-secur: a minimally invasive procedure for the treatment of primary stress urinary incontinence. One year data from a multi-centre prospective trial. Int Urogynecol J Pelvic Floor Dysfunct J 2009; 20(3):313-7.

7. Moore RD, Mitchell GK, Miklos JR. Singlecenter retrospective study of the technique, safety, and 12-month efficacy of the MiniArc ${ }^{\top M}$ single-incision sling: a new minimally invasive procedure for treatment of female SUI. Surg Technol Int 2009;18:175-81.

8. Taner CE, Okay G. [Early complications of the transobturator tape and mini sling procedure]. J Turk Soc Obstet Gynecol 2014;11(1):14-20.

9. Mostafa A, Agur W, Abdel-All M, Guerrero K, Lim C, Allam M, et al. A multicentre prospective randomised study of single-incision minisling (Ajust $($ ) $)$ versus tension-free vaginal tape-obturator (TVT-O ${ }^{\mathrm{TM}}$ ) in the management of female stress urinary incontinence: pain profile and short-term outcomes. Eur J Obstet Gynecol Reprod Biol 2012;165(1):115-21.

10. Hinoul P, Vervest HA, Bdenoon J, Venema $\mathrm{PL}$, Lakeman MM, Milani AL, et al. Randomized, controlled trial comparing an innovative single incision sling with an established transobturator sling to treat female stress urinary incontinence. J Urol 2011;185(4):1356-62.

11. Ward KL, Hilton P; UK and Ireland TVT Trial Group. A prospective multicenter randomized trial of tension-free vaginal tape and colposuspension for primary urodynamic stres incontinence: two-year follow-up. Am J Obstet Gynecol 2004;190(2):324-31.

12. De Ridder D, Berkers J, Deprest J, Verguts J, Ost D, Hamid D, et al. Single incision minisling versus a transobutaror sling: a comparative study on MiniArc and Monarc slings. Int Urogynecol J 2010;21(7):773-8.

13. Walsh CA. TVT-Secur mini-sling for stress urinary incontinence: a review of outcomes at 12 months. BJU Int 2011;108(5):652-7. 